\title{
Laporan Kasus: Amenore Primer et causa Hiperplasia Adrenal Kongenital Non Klasik
}

\author{
Maya Devi Arifiandi ${ }^{*}$, I Wayan Arsana Wiyasa ${ }^{2}$ \\ ${ }^{1}$ Program Studi Magister Kebidanan Fakultas Kedokteran Universitas Brawijaya \\ ${ }^{2}$ Departemen Obstetri dan Ginekologi Rumah Sakit Saiful Anwar Fakultas Kedokteran Universitas
}

Brawijaya

Email $^{*}$ : maderifian@gmail.com

HP : 08125269321

\begin{abstract}
Primary amenorrhea is menarche delayed at 14 of age without secondary sex or absent of menstruation at 16 of age with appearance of normal secondary sex. Congenital Adrenal Hyperplasia $(\mathrm{CAH})$ is one of endocrine disturbance can cause primary amenorrhea. Three $\mathrm{CAH}$ phenotypes are classical salt wasting and classical simple virilizing, also non classical $\mathrm{CAH}$ with late onset in symptoms and diagnosis which unknown in prenatal time. Non classical CAH caused by P450C21(21-hydroxilase) deficiency, where autosomal recessive cause by mutation of gene CYP21A2. A case 16 years old female patient came with absent of menstruation and mass near vagina as penis like. Number of screening and examination, diagnosis for this patient is Non Classical Congenital Adrenal Hyperplasia.
\end{abstract}

Keywords : primary amenorrhea, non classical congenital adrenal hyperplasia

\begin{abstract}
ABSTRAK
Amenore primer adalah tertundanya menarke pada usia 14 tahun tanpa disertai seks sekunder atau tidak adanya menstruasi pada usia 16 tahun dengan adanya pertumbuhan normal seks sekunder. Hiperplasia Adrenal Kongenital (HAK) merupakan salah satu gangguan endokrin yang dapat menyebabkan terjadinya amenore primer. Terdapat tiga fenotip HAK, HAK tipe klasik yaitu classical salt wasting dan classical simple virilizing sejak lahir serta HAK non klasik dengan late-onset baik gejala maupun diagnosisnya dimana saat prenatal tidak diketahui. HAK non klasik disebabkan karena adanya defisiensi enzim P450C21 (21-hidroksilase) yang merupakan kelainan autosomal resesif yang diakibatkan oleh mutasi gen CYP21A2. Sebuah kasus seorang pasien wanita lajang usia 16 tahun dengan keluhan belum menstruasi sama sekali dan memiliki benjolan di dekat vagina menyerupai penis. Dilakukan serangkaian pemeriksaan, diagnosis pada pasien ini adalah Hiperplasia Kongenital Adrenal Kongenital (HAK) non klasik.
\end{abstract}

Kata kunci: amenore primer, hiperplasia adrenal kongenital (HAK) non klasik 
${ }^{1}$ Korespondensi: Maya Devi Arifiandi. Surel: maderifian@gmail.com 


\section{PENDAHULUAN}

Amenore primer adalah tertundanya menarke pada usia 14 tahun tanpa disertai seks sekunder atau tidak adanya menstruasi pada usia 16 tahun dengan adanya pertumbuhan normal seks sekunder. Prevalensi amenore diketahui sekitar 3 hingga $4 \%$ pada populasi usia reproduksi dan sekitar 10-15 pasien merupakan amenore primer $^{1}$. Penyebab amenore primer terbanyak adalah kelainan genetik yaitu sekitar $43 \%$ dan penyebab terkecil adalah hymen imperforate, Androgen Insensitivity Syndrom (AIS), Hiperplasia Adrenal Kongenital (HAK), dan penyakit susunan saraf pusat yang masingmasing diketahui frekuensinya adalah sekitar $1 \%^{2}$. Evaluasi pada remaja dapat dilakukan berdasarkan dari pendekatan dengan pasien serta pendekatan berdasarkan anamnesa atau riwayat, pemeriksaan, dan investigasi dasar ${ }^{3}$.

Hiperplasia

Adrenal

Kongenital (HAK) merupakan salah satu gangguan endokrin yang dapat menyebabkan terjadinya amenore primer, dimana frekuensinya adalah sebesar $1 \%$. Terdapat tiga fenotip HAK, HAK tipe klasik yaitu classical salt wasting dan classical simple virilizing sejak lahir serta HAK non klasik dengan late-onset baik gejala maupun diagnosisnya dimana saat prenatal tidak diketahui. HAK non klasik disebabkan karena adanya defisiensi enzim P450C21 (21hidroksilase) yang merupakan kelainan autosomal resesif yang diakibatkan oleh mutasi gen CYP21A2. Dilaporkan prevalensi HAK non klasik pada wanita dengan peningkatan androgen berkisar antara $0,6 \%$ sampai $9 \%{ }^{4,5}$.
HAK non klasik dapat muncul pada berbagai usia dengan berbagai gejala-gejala hiperandrogen. Pada HAK non klasik terdapat defisiensi enzim 21hidroksilase ringan dan didiagnosis berdasarkan peningkatan serum 17hidroksiprogesteron (17-OHP). Sama seperti pada HAK tipe klasik, HAK non klasik dapat terjadi pertumbuhan prematur rambut pubis, pertumbuhan tulang yang cepat dan percepatan pertumbuhan linear yang sudah cepat. Pada wanita muncul gejala-gejala kelebihan androgen termasuk akne, hirsutisme, infertil, gangguan menstruasi, anovulasi dan ambigu seks ${ }^{4}$. Diagnosis HAK non klasik harus dibedakan dengan HAK klasik, selain dari anamnesa dan manifestasi klinis juga dari hasil pemeriksaan penunjang yaitu pemeriksaan laboratorium dan pemeriksaan radiologis. Manajemen yang diberikan untuk HAK non klasik berbeda dari HAK klasik. Penatalaksanaan yang diberikan lebih awal akan memberikan hasil yang berbeda. Monitoring juga perlu dilakukan untuk evaluasi terapi ${ }^{6}$.

Pada tinjauan kasus ini akan dibahas mengenai wanita berusia 16 tahun yang menderita HAK non klasik dengan amenore primer.

\section{Laporan Kasus}

Seorang wanita usia 16 tahun yang belum menikah datang memeriksakan diri dengan keluhan utama belum pernah haid. Riwayat lainnya adalah mengeluh payudara tidak tumbuh seperti pada temanteman seusianya serta tumbuh kumis dan rambut pada dagu. Pasien juga mengeluhkan adanya benjolan berbentuk seperti penis. Benjolan seperti penis tersebut 
baru diketahui saat pasien berusia 12 tahun, namun pasien malu untuk memberitahu kedua orang tuanya, dan baru saat 16 tahun pasien memberitahu kedua orang tuanya selain karena juga tidak kunjung haid. Menurut orang tua pasien, saat pasien masih bayi benjolan tersebut tidak ada.

Saat SD pasien memiliki badan yang lebih besar dan lebih tinggi daripada teman-teman seusianya. Namun saat menginjak kelas 2 SMP pertumbuhan badan pasien tetap, dan tampak lebih kecil dibandingkan oleh teman-temannya. Riwayat adanya keluarga dari ibu (adik perempuan dari nenek ibu pasien) meninggal pada saat masih kecil, tidak diketahui sebabnya.

Dari pemeriksaan fisik tinggi badan $145 \mathrm{~cm}$, berat badan $41 \mathrm{~kg}$. Dari kepala tampak kumis tipis dan akne yang tersebar di daerah pipi kiri dan kanan. Dari pemeriksaan thorax rambut ketiak ada dan agak lebat serta payudara Tanner 1. Dari abdomen tampak rambut di linea mediana. Rambut pubis sesuai dengan Tanner 5. Genetalia eksterna tampak klitoris membesar dengan ukuran $3 \times 1 \mathrm{~cm}$. Hymen intak, liang vagina ada dengan sondasi $8 \mathrm{~cm}$ dari introitus vagina.

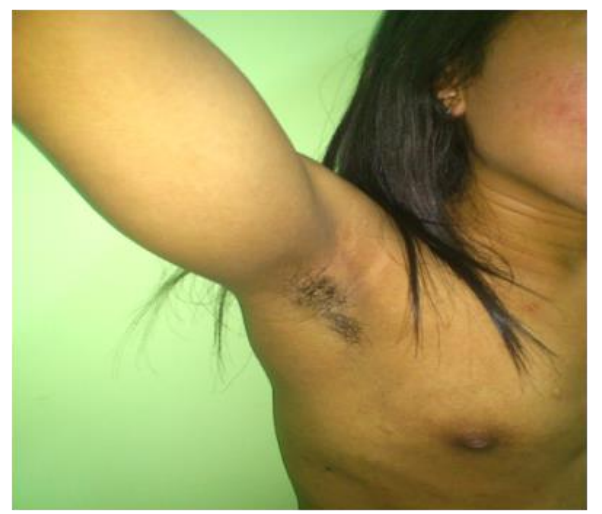

Gambar 1. Bulu ketiak dan akne pada pipi

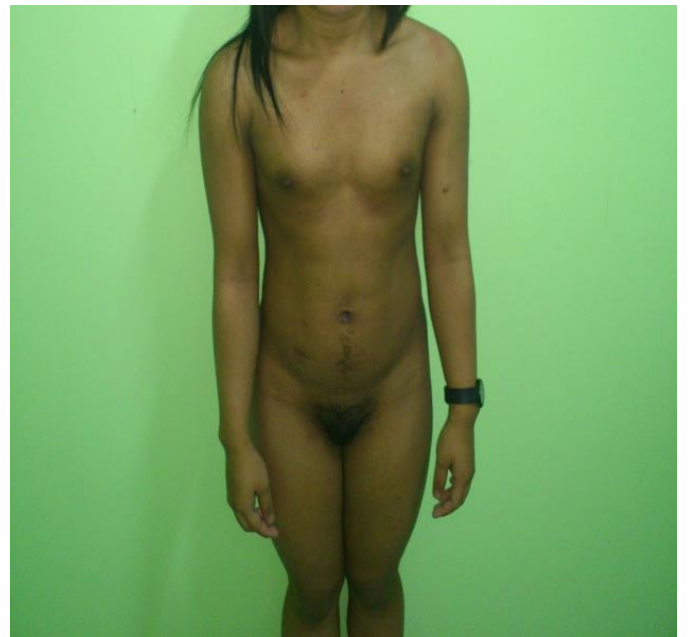

Gambar 2. Payudara sesuai dengan Tanner 1 dan rambut pubis sesuai dengan Tanner 5

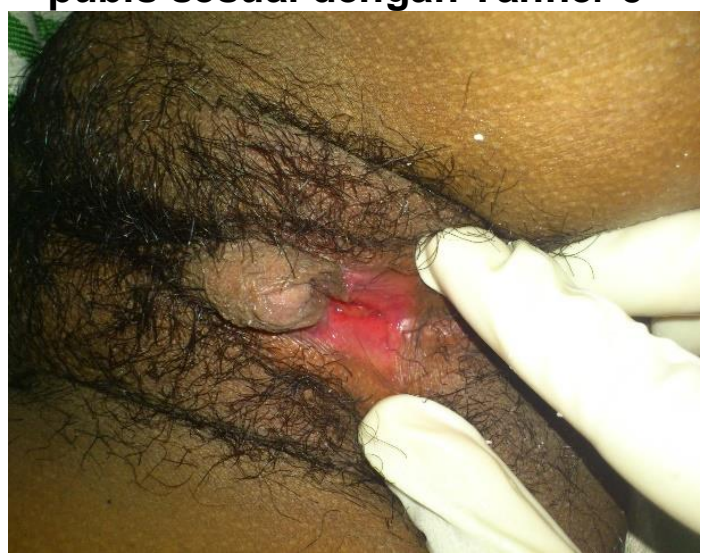

Gambar 3. Klitoris membesar

Pemeriksaan laboratorium pada pasien ini didapatkan kadar LH: $\quad 6,83 \mathrm{mIU} / \mathrm{mL}, \quad$ FSH: 5,20 $\mathrm{mIU} / \mathrm{mL}$

Testosteron: $\quad 372,80 \quad \mathrm{mlU} / \mathrm{ml}$, Estradiol: $17,00 \mathrm{pg} / \mathrm{mL}$, DHEAS: 752,4 $\mu \mathrm{g} / \mathrm{dL}$, dan 17 - OHP: 937,0 $\mathrm{nmol} / \mathrm{L}$. Dilakukan pemeriksaan karyotyping dengan hasil Mosaic 45, $X[7]$ / 46, XX [36].

Pada USG Ginekologi tampak gambaran uterus antefleksi ukuran $60,5 \times 31,7 \mathrm{~mm}$. Tidak didapatkan massa patologis pada adnexa. 


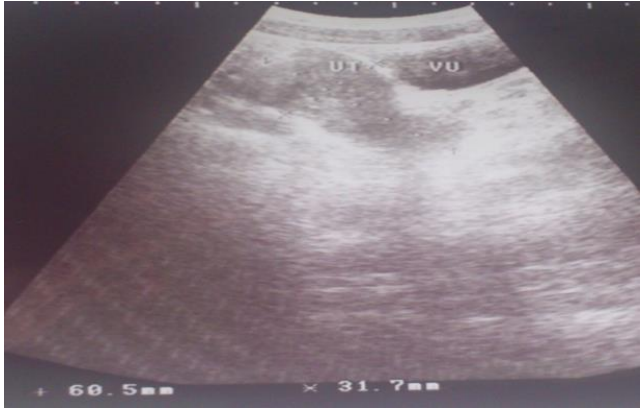

Gambar 4. Uterus (Ut) dalam batas normal yang tampak di belakang vesika urinaria (VU)

Dari MRI didapatkan ren dekstra/sinistra: ukuran normal, intensitas korteks normal, sistem pelviokaliseal tak melebar, tidak tampak massa solid/kistik, tampak kelenjar adrenal kanan kiri intesitas homogen, ukuran (D) $4 \times 1,2 \mathrm{~cm},(\mathrm{~S})$ $3,2 \times 1,9 \mathrm{~cm}$ atau dengan kesimpulan pembesaran kelenjar adrenal bilateral.

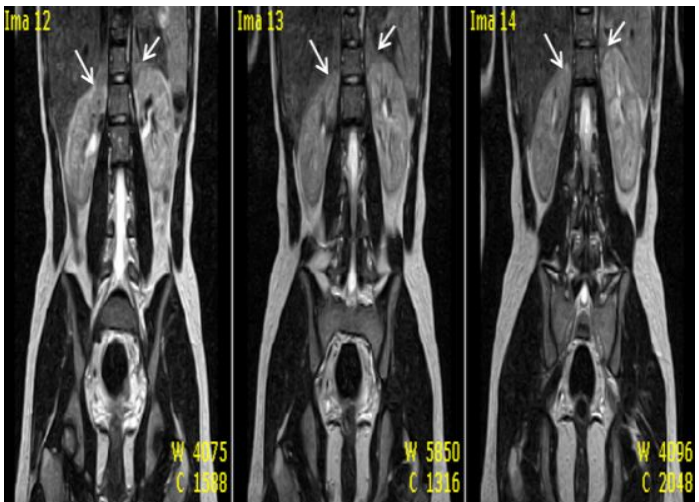

Gambar 5. Hasil MRI yang menunjukkan adanya pembesaran adrenal bilateral (tanda panah)

Foto Manus hasilnya adalah bone age perempuan usia 16 tahun sesuai umur.

\section{Dilakukan} laparoskopi diagnostik dengan hasil Uterus normal, tuba dekstra/ sinistra normal, ovarium dekstra/sinistra normal, folikel (+). Cavum Douglassi bebas. Tidak didapatkan perlekatan antar organ.
Sedangkan dari hasil vaginoskopi adalah vagina dalam batas normal, panjang $\pm 7-8 \mathrm{~cm}$, serta portio dalam batas normal.

\section{PEMBAHASAN}

Amenore primer dapat ditegakkan bila pasien secara karakteristik memiliki seks sekunder namun belum mengalami menarche sampai dengan usia 16 tahun. Perubahan saat pubertas terjadi saat periode tiga tahun dan dapat diukur menggunakan Tanner Staging. Perkembangan normal pada pubertas seorang wanita dapat dilihat dari ilustrasi gambar pada gambar $6^{7,8}$. Pada pasien ini ditemukan kriteria yang memenuhi amenore primer, dimana belum menarche saat usia 16 tahun dan didapatkan adanya seks sekunder yaitu dan rambut pubis sesuai dengan Tanner 5. Pertumbuhan payudara pasien ini tidak mewakili pertumbuhan seks sekunder, sesuai dengan Tanner 1, disebabkan karena terjadi peningkatan testosteron, sehingga terjadi kompetitif dengan estrogen untuk menempati reseptor pada payudara, sehingga pertumbuhan payudara pada pasien ini terhambat.

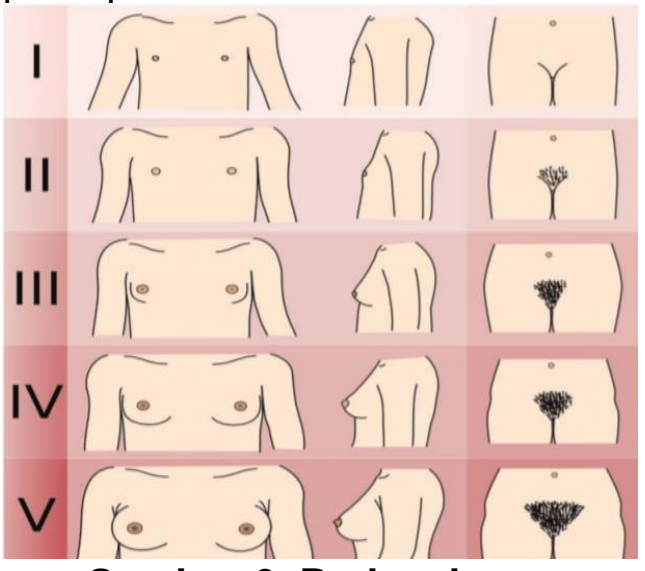

Gambar 6. Perkembangan pubertas wanita menurut Tanner

(7) 
Pada pasien ini dilakukan anamnesis, dimana tidak didapatkan riwayat penyakit dan penggunaan obat-obatan sebelumnya. Untuk riwayat penyakit keturunan dalam keluarga disangkal. Dari pengukuran tinggi badan, pasien termasuk pendek bila dibandingkan dengan tinggi badan rata-rata wanita seusianya. Ini disebabkan karena penutupan epifiseal plate yang lebih cepat akibat dari tingginya kadar sex steroid, berakhir dengan hasil glucocorticoid induced inhibition of growth axis ${ }^{9}$ Dari pemeriksaan fisik didapatkan payudara sesuai Tanner 1 dan rambut pubis sesuai Tanner 5, didapatkan vagina dengan sondase $8 \mathrm{~cm}$.

Etiologi terjadinya amenore primer pada pasien ini dapat dijabarkan melalui gambar skema dibawah ini :

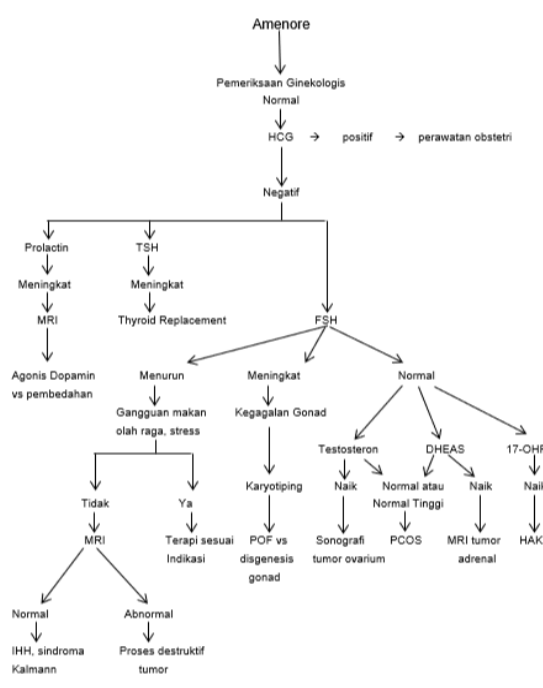

Gam

\section{bar 7. Algoritme evaluasi amenore (2)}

Pada pasien ini amenore diluar aksis hipotalamus-hipofiseovarium. Pada pasien ini telah dilakukan USG, MRI dan laparoskopi diagnostik. Dari USG dan laparoskopi diagnostik, pada pasien ini didapatkan uterus dan adneksa yang normal. Pada MRI ditemukan adanya kelainan adrenal dimana terdapat pembesaran kelenjar adrenal bilateral.

Tabel 1. Pemeriksaan yang paling sering digunakan untuk evaluasi amenore (2)

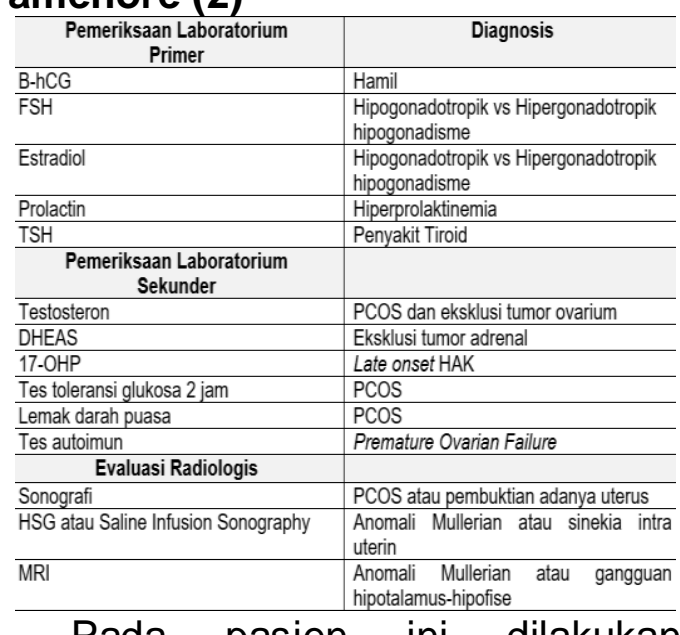

Pada pasien ini dilakukan pemeriksaan laboratorium yaitu DL, SGOT/SGPT, albumin, ureum/kreatinin, serum elektrolit (natrium/kalium/klorida), T3/free T4/TSH, FSH, LH, estradiol, testosteron, DHEAS,GDA, GDP, GD2PP, HbA1c 17-OHP. Dari semua hasil laboratorium tersebut menunjukkan bahwa terjadi peningkatan testosterone, DHEAS. Kemudian juga dilakukan pemeriksaan USG dimana terlihat adanya uterus dan tidak ada kelainan pada adneksa baik kanan maupun kiri. Dilanjutkan pemeriksaan laparoskopi diagnostik dimana uterus dalam batas normal,tuba dan ovarium kanan dalam batas normal, tuba dan ovarium kiri dalam batas normal. Durante laparoskopi diagnostik tampak adanya folikel pada ovarium, kemudian dilakukan biopsi. Hasil PA dari biopsi tersebut tidak didapatkan folikel, ini bisa terjadi mungkin pengambilan jaringan yang kurang dalam. Vaginoskopi juga 
dilakukan pada pasien ini dimana vagina normal, dengan panjang sekitar $8 \mathrm{~cm}$, dan terdapat portio. Hasil MRI pada pasien ini menunjukkan adanya pembesaran kelenjar adrenal bilateral. Dilakukan konfirmasi dengan pemeriksaan 17$\mathrm{OHP}$, hasil meningkat. Peningkatan DHEAS pada pasien ini disebabkan karena produksi kortisol dan aldosteron rendah akibat defisiensi enzim 21-hidroksilase sehingga kelenjar adrenal bekerja lebih keras lagi untuk meningkatkan kadar kortisol, sehingga terjadi hiperplasi dari adrenal. Namun kortisol yang dihasilkan tidak mencukupi sehingga produksi testosteron meningkat. Peningkatan 17-OHP pada pasien ini disebabkan karena defisiensi enzim 21- hidroksilase, dimana enzim ini seharusnya merubah 17-OHP menjadi 11deoksikortisol dan progesteron menjadi deoksikortikosteron, akibatnya kadar 17-OHP menjadi tinggi pada pasien ini. Dengan demikian menunjukkan bahwa terjadinya amenore primer pada pasien ini disebabkan karena Hiperplasia Adrenal Kongenital (HAK) non klasik.

\begin{tabular}{|c|c|c|c|}
\hline & \multicolumn{3}{|c|}{ Klasifikasi Klinis } \\
\hline & Salt Wasting & Simple virilizing & Non klasik \\
\hline Usia saat diagnosis & Neonatus - 1 bulan & Neonatus - 2 tahun & Anak-dewasa \\
\hline Genetalia eksterna & Ambigu & Ambigu & $\begin{array}{l}\text { Biasanya normal, } \\
\text { terkadang } \\
\text { kiltoromegali }\end{array}$ \\
\hline Aldosteron & Rendah & Normal & Normal \\
\hline Renin & Tinggi & $\begin{array}{l}\text { Pada beberapa kasus } \\
\text { tinggi } \\
\end{array}$ & Normal \\
\hline Kortisol & Rendah & Rendah & Normal \\
\hline 17 OHP & Basal $>20.000 \mathrm{ng} / \mathrm{dL}$ & $\begin{array}{l}\text { Basal>10.000-20.000 } \\
\mathrm{ng} / \mathrm{dL}\end{array}$ & $\begin{array}{l}\text { Stimulasi ACTH: } \\
1500-10.000 \text { ng/dL }\end{array}$ \\
\hline Testosteron & Tinggi & Tinggi & Tinggi, bervariasi \\
\hline Terapi & $\begin{array}{l}\text { Glukokortikoid + } \\
\text { mineralokortkoid } \\
(+ \text { garam })\end{array}$ & $\begin{array}{l}\text { Glukokortikoid } \\
\text { (+mineralokortikoid) }\end{array}$ & $\begin{array}{l}\text { Simptomatik: } \\
\text { glukokortikoid }\end{array}$ \\
\hline Insidens & 1:15.000 & 1:60.000 & 1:1.000 \\
\hline $\begin{array}{l}\text { Presentase aktifitas } \\
\text { 21-hidroksilase }\end{array}$ & 0 & 1.2 & 20.50 \\
\hline
\end{tabular}

Tabel 2. Gambaran klinis dan hormonal pada hyperplasia adrenal kongenital (10)
Sedangkan pada pemeriksaan kryotiping didapatkan hasil Mosaic 45, X [7] / 46, XX [36]. Seringkali hasil ini misdiagnosis dengan Turner syndrome. Pada Turner syndrome tidak terjadi virilisas ${ }^{11}$. Pada pasien ini terjadi virilisasi, sehingga disingkirkan diagnosis Turner syndrome.

\section{KESIMPULAN}

welah dilaporkan kasus dengan Amenore Primer pada Hiperplasia Adrenal Kongenital (HAK) non klasik.

Pendekatan diagnosa terhadap amenore primer ditegakkan menggunakan pendekatan melalui Tanner Staging, kategori fenotip Brenner, pendekatan Speroff, pendekatan ASRM , pemeriksaan laboratorium, pemeriksaan radiologis, laparoskopi diagnostik, pemeriksaan karyotyping, dan vaginoskopi. Dari semua pendekatan dan pemeriksaan yang telah dilakukan maka diketahui bahwa amenore primer disebabkan oleh HAK non klasik.

HAK non klasik disebabkan karena defisiensi enzim 21hidroksilase sehingga terjadi gangguan produksi kortisol dan aldosteron (menjadi rendah) sehingga produksi testosteron menjadi berlebihan yang berakibat virilisasi genetalia eksterna, hirsutisme dan gangguan menstruasi pada kasus ini. Kadar 17-OHP yang menentukan tipe dari HAK.

\section{DAFTAR PUSTAKA}

1. ASRM, The practice committee of the American Society for Reproductive 
Current evaluation of amenorrhea, fertility and sterility, 2009; Vol.86.148-155.

2. Hoffman BL, Schorge $P$, Bradshaw KD et al. William Gynecology Third Edition, Mc Graw Hill, 2016; p:369-378.

3. Hayden CJ, Balen AH, Primary Amenorrhea: Investigation and Treatment. Obstetrics Gynaecology Reproductive and Journal, 2007; p17:7.

4. Witchel SF, Azziz R. Nonclassic congenital adrenal hyperplasia, International journal of pediatric endocrinology, 2010; Vol.10: 1155-1166.

5. Trakakis E, Rizos D, Loghis D, Chryssikopoulos $A$, et al. The Prevalence of Non -Classical Congenital Adrenal Hyperplasia due to 21Hydroxylase Deficiency in Greek Women with Hirsutism and Polycystic Ovary Syndrome, Endocrine Journal ; 55: 33-39, 2008.

6. Baskin LD, Azzis R, Miller W et al. Diagnosis Congenital Adrenal Hyperplasia, The Endocrine Society Journal, 2010, p: 14-16

7. Roberts C. Tanner's Puberty Scale Exploring The Historical Enlargement of Children, Scientific Photography and Sex, SagePub Journal, 2016; Vol.19(3): 328-346

8. Speroff L, Fritz $M$, et al. Amenorrhea in clinical gynecologic endocrinology and fertility, Lippincott William and wilkins, Philadelphia, 2011; p: 401-463.

9. Speiser P, Azzis R, Baskin LS, Ghizzoni L, et al. Congenital adrenal hyperplasia due to steroid 21-hydroxylase deficiency: an endocrine society clinical practice guidline, Journal of clinical endocrinology and metabolism, 2010; Vol.95 (9): 4133-4160.

10. Batubara JR, Tridjaja B, Pulungan $A$, et al. Endokrinologi anak, Buku ajar endocrinology anak,UKK endokrinologi anak dan remaja IDAI, edisi I, 2010, p: 245-291.

11. Mishra VV, Pritti K, Agarussal $\mathrm{R}$, Choudary K, Non classic congenital adrenal hyperplasia misdiagnosed as Turner syndrome, Journal of Human Reproductive Sciences, 2015; Vol.8: 239-241. 